\title{
Communication
}

\section{Influence of Policy Making in the Profitability of Forage Production Irrigated with Reclaimed Water}

\author{
María del Pino Palacios-Diaz ${ }^{1, \dagger, *}$, Vanessa Mendoza-Grimón ${ }^{1, \dagger}$ and Alberto Del Villar Garcia ${ }^{2, \dagger}$ \\ 1 Dpto Producción Animal, Grupo Investigación GEOVOL, Universidad de Las Palmas de Gran Canaria, \\ Fac. Veterinaria, Arucas 35013, Spain; E-Mail: v.mendozagrimón@ulpgc.es \\ 2 Departamento de Economía y Dirección de Empresas, Facultad de Ciencias Económicas, \\ Universidad de Alcalá, Alcalá de Henares 28802, Spain; E-Mail: alberto.delvillar@uah.es \\ $\dagger$ These authors contributed equally to this work. \\ * Author to whom correspondence should be addressed; E-Mail: mp.palaciosdiaz@ulpgc.es; \\ Tel.: +34-928-454-353; Fax: +35-928-451-142.
}

Academic Editor: Andreas Angelakis

Received: 13 April 2015 / Accepted: 28 July 2015 / Published: 4 August 2015

\begin{abstract}
The limited availability of water at low prices and the current scheme for specific supply arrangements (SSA/REA), both determined at the political level, explain that the goal of being self-sufficient in terms of forage consumption is currently unattainable in the Canaries. The "PFORCA" Plan aims to counteract this reality and increase their level of self-sufficiency. The financial aid relating to the REA reduces the amount payable for the imported fodder (annual 83,000 t) versus local product, which influences the decision making by farmers. According to calculations, performed by reusing the water instead of discharging, Maralfalfa production could be competitive against imports, being financially viable with water prices in a range of $0.20-0.30 € / \mathrm{m}^{3}$ (prices perfectly acceptable for reclaimed water with low levels of treatment, but fulfilling requirements reuse of Spanish law, RD 1620/2007). The economic contribution of forage crops could represent the creation of 640 new jobs, the enhancement of land currently abandoned, plus an increase in Gross Domestic Product (GDP) of the archipelago on more than 23 million $€(M €)$, product of the substitution of imports by local production. Also, it would help to save the REA's aid (6 M€).
\end{abstract}


Keywords: Pennisetum sp; reclaimed water; financial aid; forage production; Gross Domestic Product

\section{Introduction}

The proposal of a predominant economic intervention in markets has three overarching objectives: productive effectiveness in order to maintain a momentum that allows reinforcement in the economic growth; changes in levels of equity of wealth distribution and economic stability, in favor of reaching a sustainable adaptation to the economic cycle and keeping pricing levels.

The current legal framework of Régimen Especial de Abastecimiento (REA, Specific Supply Arrangement SSA) pursues (or at least it should be) those objectives. On one hand, it does not prejudice the productive capacity of certain agents which require productive inputs that are inaccessible under unfavorable economic conditions in the action taken specifically with a view to reducing the accessibility deficit of the Outermost Regions (Effectiveness). Further, the system is designed to reduce the shopping basket of canaries people (Equity).

However, not intervention is neutral. When any economic sector is protected, other is no longer protected, distorting trading conditions on the market. This is the case of the fodder crops sector, unprotected in the Canary Islands due to aids for the livestock sector by subsidies for dried fodder.

The effects of this policy are not so important in economics size (over $6 \mathrm{M€/yr}$ ), but the impact in fodder crops sector shall be taken into account. The purpose of this paper is to raise awareness the large effects of these small policies, describing how can be missed economic factors and resources, while formally the opposite is claiming.

Firstly, we analyze the financial results of a high growth fodder crop (Maralfalfa, Pennisetum sp, a $P$. purpureum hybrid) that can be optimally adapted to certain zones of the Canary archipelago. Over this microeconomic target, we will be able to show the effects over the macroeconomic figures as the Gross Domestic Product (GDP), issue we address secondly.

\section{Maralfalfa Production in the Canary Islands: Domestic Production vs. Import-Economic Aspects}

This section aims to compare the main data of the Canary Specific Supply Arrangement (SSA/REA) in reference to dried fodder imports for cattle breeding, and comparing the possibility of substituting these imports by local production.

The main objective of this section is not to formulate a general economic theory over an import substitution industrialization growth models (known by its acronym ISI), but to provide an overview of a policy of incentives in the way to protect an economic sector from the external competition.

\subsection{The Policy of Import Substitution: Advantages and Disadvantages}

Any protectionist measure has two sides as a coin, a head that favors certain economic operators (producers, importers or customers) beneficiaries of the measure and a tail, weighing down certain 
economy sectors, such restriction leads to a lower efficiency and higher costs of production in the Canaries.

Protectionist measures can be justified when concerns regarding the maintenance of competitive conditions for certain industries. The implementation of these measures marks the recognition of the weakness of the sector in order to compete under equal conditions in a globalised market. This weakness may be determined by a multiplicity of factors, of a political and economic nature. An example of protectionist measures, as we have pointed out in this paper, is the Canary Specific Supply Arrangement.

Originally, the SSA was an essential tool to reduce the shopping basket of canary's people and for developing local agricultural production enabling to incorporate factors of production for farmers and livestock breeders with preferential conditions due the remote location of the Canary Islands. In this particular case, we study the financial support to the imports of dried fodder from other parts of the UE.

The application of the aid in question allows to a decrease in the production costs (for) of the livestock sector, providing financial assistance to cover transportation costs from the origin to the Canary Islands. This supposes lower costs of fodder and a decrement in the price for the farmers. The measure has promoted intensive production of local livestock sectors, even in the driest islands, increasing environmental risks.

Also, in our opinion, this economic policy causes an inefficient allocation of resources due a fictitious price of the dried fodder, meaning an economic loss quantified in this paper.

A partial import substitution of dried fodder could have positive effects across the whole economy of the Canary Islands. In the report of some extent lists, we point out the positive impact of savings income in the form of imports, the development of local economy (GDP), the use of unused productive factors (like recycled water, former cultivated lands, labour factor, assets, etc.), saving in public funds (reducing subsidies and gradually increase taxes due the economic activity growth) and environmental improvements.

According to this line of thinking, currently the new Canary Fodder Action Plan 2014/2020 [1] is being developed, as mentioned in its introduction: "We need to develop fodder crops which generate local employment, to encourage maintaining people in rural areas and improve on-farm consumption in our region". However, in our opinion, if the arguments presented in this paper are not taking into account, the last objective will hardly be achieved.

On the other side of the coin, we have to quantify any possible short-term cost increases for livestock producers, in order to know fodder import substitution balance. In principle, if current dried fodder price levels are maintained, it would have no major impact on livestock sector, being a neutral impact measure.

Also, we have taking into account the resources diverted into dried fodder production, mainly from water and land availability for this activity. In this case, we consider that the rules should stay as neutral as possible limited to the financial resources implemented in this measure as same as the actual the Canary Specific Supply Arrangement (SSA). 


\subsection{The Cost of Fodder Production: Banishing Myths}

One of the arguments used as a basis of the SSA is the failure of the Canary Islands' market to satisfy the demand of some economic sectors. We would like to use an apt example to illustrate that this is clearly not the case.

Recent local experimental studies [2] have shown an estimated average production around $90 \mathrm{t}$ per hectare and year (89.64 t/ha·yr). This production level will be our reference in order to calculate financial balances.

Investment requirements facilities have been quantified around 51,200 €/ha. These estimated amounts have been calculated in addition of the following key components:

- Irrigation systems: $18,000 € /$ ha.

- Acquisition of new agricultural machinery; 32,300 €/ha.

- Development and maintenance of farming systems: $900 € /$ ha.

Being cautious calculating investment costs and the economic life of the assets, we can assume an annual cost of investment in agricultural machinery of $10 \%$, and $20 \%$ for the implementation capital. This could imply an annual cost of investment capital up to $5210 € / \mathrm{ha} \cdot \mathrm{yr}$.

The estimated amount of the land use has been quantified around $1951 € / \mathrm{ha} \cdot \mathrm{yr}$, according to farming land prices in the Canary Islands [3].

The labor force of the agricultural holding has been estimated in these terms: $9 \mathrm{~d} / \mathrm{ha} \cdot \mathrm{yr}$ tractor driver; $9 \mathrm{~d} / \mathrm{ha} \cdot \mathrm{yr}$ workers for harvesting labors and a part time farmworker ha/yr. We consider just the last one as direct labor force, because tractor driver and workers for harvesting can be contracted out. It supposes an amount of $9000 € / \mathrm{ha} \cdot \mathrm{yr}$ (Considering a full-time cost of $18,000 € / \mathrm{ha} \cdot \mathrm{yr}$ ).

The farming supplies per hectare and year consist essentially of fertilizers $(\mathrm{N}, \mathrm{P}, \mathrm{K})$ and plant protection products. The average cost for fertilizing has been estimated in $3173 € / \mathrm{ha} \cdot \mathrm{yr}$; and the plant protection products cost is calculated around $200 € /$ ha·yr. Total farming supplies amount up to $3373 € /$ ha $\cdot y r$.

Finally, we have other direct costs of different activities (tractor renting, transportation cost, etc.), which have been estimated at $2520 € /$ ha $\cdot y r$ (Table 1$)$.

Table 1. Cost of fodder production in terms of $€$ per ha and year and $€$ per $t$ of dry matter.

\begin{tabular}{ccc}
\hline Cost & $\boldsymbol{\epsilon} / \mathbf{h a} \cdot \mathbf{y r}$ & $\boldsymbol{€} / \mathbf{t}$ \\
\hline Land (Capital) & 1951 & 22 \\
Others (Capital) & 5210 & 58 \\
Supplies & 3373 & 38 \\
Labour force & 9000 & 100 \\
Others & 2520 & 28 \\
Total & $\mathbf{2 2 , 0 5 5}$ & $\mathbf{2 4 6}$ \\
\hline
\end{tabular}

We have estimated the annual production per hectare of $90 \mathrm{t}$, so the average cost of production is estimated at some $246 €$. The cost will be added to the water irrigation prices paid by the farmers. 
This figure banished myths of non-viable or unfeasible costs for planting fodder crops, the increase in dried fodder prices means that it has to be imported (with subsidies) from other regions or countries to reduce costs.

\subsection{Gains in GDP and Employment: Increase in Disposable Income}

The numbers quoted below implemented in 926 ha will be enough to replace current imports of dried fodder. In order to review its effects on economic activity and employment (substitution of fodder import subsidies), requires complex economic analysis (such as an econometric study based in Input-Output models). However, the last I/O data of the Canary Islands economy are from 2005 (10 years ago). Since last decade, the structural changes have been so large that would invalidate any results that may be obtained by using them. Nevertheless, we can solve this obstacle analyzing the main productive factors and resources used to produce dried fodder. If we add every of those factors we can quantify the direct effects over the economy and the GDP figure.

All these aggregated data are the result of an economic activity generated by local production of fodder due import, activity that does not generate productive activity in this sector.

In line with the foregoing, we can obtain the economic aggregates from the estimated costs of fodder production. These economic aggregates are as follows: Salaried Worker Compensations (labour costs), Gross Operating Surplus (earned by the capital factor), and others. In this way we can measure the direct impact over the GDP (Table 2).

Table 2. Aggregate GDP of Maralfalfa production.

\begin{tabular}{ccccc}
\hline \multirow{2}{*}{ GDP Aggregates } & \multicolumn{3}{c}{ Value } \\
\cline { 2 - 5 } & Per ha & Per Tm & Total \\
\hline \multicolumn{2}{c}{ Salaried Worker Compensations } & 9000 & 100 & $8,333,333$ \\
\multirow{3}{*}{ Gross Operating Surplus } & Land & 1951 & 22 & $1,806,797$ \\
& Other capital & 5210 & 58 & $4,824,074$ \\
& Other Inputs & 2520 & 28 & $2,333,333$ \\
SSA Subsidies & 6454 & 72 & $5,976,000$ \\
\multicolumn{2}{c}{ Total } & $\mathbf{2 5 , 1 3 5}$ & $\mathbf{2 8 0}$ & $\mathbf{2 3 , 2 7 3 , 5 3 8}$ \\
\hline
\end{tabular}

Notes: Data are in $€$ per hectare, $t$ and total. It is not included irrigation costs or indirect costs. Total value has been calculated for around 926 ha and $83,000 \mathrm{t}$ of dried fodder production.

It is estimated that these measures will create approximately 537 jobs directly, and produce $83,000 \mathrm{t}$ of dried fodder. The indirect jobs generated, by conservative estimates, could reach about $20 \%$ in addition, achieving a total of 644 full-time jobs. This means a contribution to real GDP growth by salary income of 9.3 M€ (8.3 M€ by direct jobs and $1 \mathrm{M} €$ by indirect jobs).

The three estimated Gross Operating Surplus (GOS) components can provide an additional economic growth of $9 \mathrm{M} €$. The first component, land rents, would give 1.8 M€. This figure is obtained as a result of capitalize land price (4\%, 25 years), and means land use cost or land lease cost. Land prices are obtained as a result of carrying out the Land Price Survey [3], reaching an amount of $30,484 € /$ ha for grasslands. 
The second considering component of the GOS (other capital) is fixed in $4.8 \mathrm{M} €$. These investments were mainly related to direct investments in agricultural machinery and equipment, as well as in harvesting and storage facilities. An average per hectare estimated in $5210 €$.

The third part of the GOS (other inputs) adds $2.3 \mathrm{M} €$ from others economic activities (tractor rents, transport, grass harvesting machine, etc.) not belonging to the agricultural holding. Per hectare, it has been calculated a value of $2520 €$.

Al last, we can consider as an economic growth the effectively savings income in the form of unrealized subsidies of the Canary SSA. This item is budgeted at $6 \mathrm{M} €$.

To sum up, import substitution of dry fodder can add an economic growth for the Canary Islands estimated in an extra $23 \mathrm{M} €$, just estimating direct effects. Indirect effects are more difficult to estimate, but we can consider a very conservative estimate of an average of $30 \%$ of direct economic growth.

In essence, it is not new generated income, since it partially reflects the income replacement from other territories and regions from which these products are imported. In fact, it would be a geographic or territorial income replacement due to a change in productive factors (local producers $v s$. imports).

In order to complete this study we should actually determine the elements on which the success of this measure depends: disused productive factors and their costs.

In the case of availability of suitable land for cultivation, it is sufficient to note that actually in Tenerife Island almost $57 \%$ of total agricultural land $(24,000$ ha) has been left uncultivated [4]. On the other hand, there is not a shortage of manpower (33\% of unemployment rate at the end of the last year [5]).

However, water availability is a critical factor in regard to both price and quantity. It would require making available to fodder crops an additional amount of $24,000,000 \mathrm{~m}^{3}$ of water. In this sense, some authors had analyzed the benefits and risks associated with reclaimed water irrigation to demonstrate that it is a safe water resource when appropriately applied [6]. An interesting paper [7] concluded that cooperative demand management was found to be the key factor controlling the robustness of regional water supply planning, dominating other hydro climatic and economic uncertainties through the 2025 planning horizon. On the other hand, Philip et al. [8] studied alternatives that combine irrigation water pricing strategies and improved technology. Their study confirmed that the absence of price volatility achieved through a water pricing strategy could improve the sustainable use of water. Following their conclusions, and as Aguilera-Klink et al. [9] pointed out, water resources can be consider under two points of view: the notion of aquifer and water as a capital asset and commodity, as opposed to the notion of water as an eco-social asset or common property. If the institutional framework regulates water reuse as described by [10], assigning it a reasonable price, the new availability of reclaimed water will provide a new resource and, consequently, water would be considered as a commodity. Therefore, the forage production sector can be properly supported considering their water demand in water planning, just assigning a rational price to the water. As water quality is not the main problem because this crop does not need high quality water, we can use low-cost treatments to regenerate water. In this sense, Palacios et al. [11] have argued that the cost would depend very much on treated effluent quality, which can range from $0.22 € / \mathrm{m}^{3}$ (if regenerated water quality allows the direct irrigation) to $0.42 € / \mathrm{m}^{3}$ (if a desalination treatment would be necessary). To this we would also have to add pumping costs (estimated in $0.08 € / \mathrm{m}^{3}$ every $100 \mathrm{~m}$ ). Hence, water scarcity is not a limiting factor, because only 
in Gran Canaria Island 37,400,000 $\mathrm{m}^{3}$ of treated and not treated waste water are discharged at sea every year [12].

Since the resource available does not suppose a constraining factor on fodder production, we focus on the water prices analysis in order to determine the break-even point and the efficiency of this measure. According to the price per unit of water, we can obtain a linear increasing cost function, as is seen in the Figure 1.

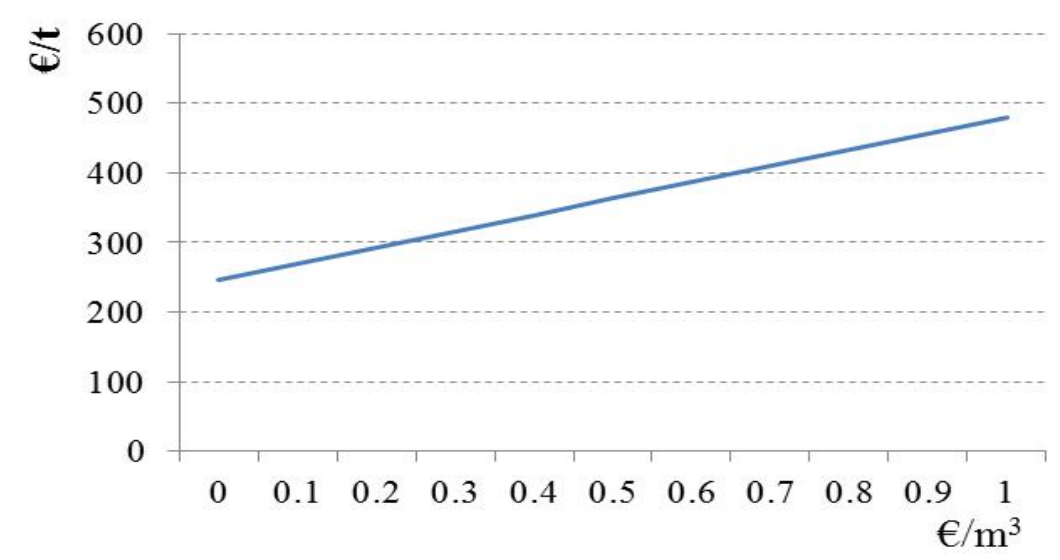

Figure 1. Production cost $(€ / \mathrm{t})$ as a function of the water price $\left(€ / \mathrm{m}^{3}\right)$.

Based on this production function, the break-even point (a cost of $350 € / \mathrm{t}$ ) place water prices in an average range between $0.40-0.50 € / \mathrm{m}^{3}$. All water prices below this value improve its profitability and thereby ensure the economic viability of this measure. Recent studies show that it is possible to improve crop earnings as a result of production increases in specific agro-climatic conditions.

Finally, alongside this economic approach we can consider the environmental and social benefits that can be expected from this measure. To illustrate the wide range of potential benefits, and while not intended to be an exhaustive list, we could point to reduce waste water discharges, prevents surface runoff and erosion, less energy (fuel) will be used and that the emission of $\mathrm{CO}_{2}$. We could add as social benefits the revitalization of the rural areas, increases in the income generated by agricultural activity and reduce in the unemployment rate.

\section{Conclusions}

The limited availability of water at low price (which in the case of reclaimed water is determined by water managers and officially published), and the current scheme for specific supply arrangements (REA), that reduces the amount payable for the imported fodder against the local production, both decided at the political level, explain that the forage self-sufficiency is currently an unattainable goal in the Canaries. In fact, the fodder crop sector is under protected in the Canary Islands due to the existence of support for the livestock sector in terms of fodder import subsidies.

It is feasible to promote a policy of import substitution (which does not generate productive activity in the livestock sector) by fodder production, when choosing high productivity species. But, to consider whether this measure is optimal and efficient, in this article the various production factors are analyzed, all currently unused, less the one which really acting as a key factor, which is available water (quantity and price). Thus, according to the calculations, it is shown that it is possible to locally 
produce forage species reusing the water instead of discharging it, being financially viable with water prices in the range of $0.20-0.30 € / \mathrm{m}^{3}$ (assumable for reclaimed water with a level of treatment compliance with the laws of reuse). Therefore, the production of Maralfalfa could be competitive with imports, an economic activity that would generate profits in GDP (which can be estimated that more than $23 \mathrm{M} €$ ) and increased income. In addition to the increase in GDP, the economic contribution of these crops could represent the creation of 640 new jobs and the enhancement of land currently abandoned. Under this assumption, saving the REA aid for imports would be $6 \mathrm{M} €$. If this amount (or part thereof) would be used to promote local forage production, profitability would be even greater. This quantity could be allocated, for instance to pay infrastructures for water distribution, could be subsidized part of the cost of reclaimed water, or the construction of infrastructures necessaries for reclaimed water reuse to irrigate of abandoned land. The amount of these payments would avoid an outflow of resources (imports) to become inner resources of the Canary Islands. It would not be an actual income generated but it would replace income from other territories due to the fact that, at present, these products are imported from outside the Canary Islands. It would need to be clarified this measure that would be a simple geographical income substitution, since it let replace to retributions from external productive factors to local ones.

\section{Acknowledgments}

This work was funded by Spanish Ministerio de Economía y Competitividad (MINECO) (CGL2012-39520-C03-03), Fondo Europeo de Desarrollo Regional (FEDER) and Agencia Canaria de investigación (from Canary Islands: SolSubC200801000012). The authors also wish to thank Emiliano Fernández Armas by the contributed ideas.

\section{Conflicts of Interest}

The authors declare no conflict of interest.

\section{References}

1. Consejería Agricultura Gobierno de Canarias. Plan Forrajero de Canarias 2014/2020 (PFORCA, 2014). Available online: http://www.gobiernodecanarias.org/agricultura/agricultura/pforca/ (accessed on 23 July 2015). (In Spanish)

2. Palacios-Díaz, M.P.; Mendoza-Grimón, V.; Fernández-Vera, J.R.; Hernández-Moreno, J.M. Effects of defoliation and nitrogen uptake on forage nutritive values of Pennisetum sp. J. Anim. Plant Sci. 2013, 23, 566-574.

3. Instituto Nacional de Estadística. Encuesta de Precios de la Tierra 2012. Available online: http://www.magrama.gob.es/es/estadistica/temas/estadisticas-agrarias/economia/encuesta-preciostierra/ (accessed on 23 July 2015). (In Spanish)

4. Lesourd. Los Cultivos en Tenerife: Aspectos Territoriales; Servicio Técnico de Agroindustrias e Infraestructura Rural, Cabildo Insular de Tenerife: Santa Cruz de Tenerife, Spain, 2012; p. 39. (In Spanish) 
5. Instituto Nacional de Estadística. Encuesta de Población Activa de las Islas Canarias: II Trimestre 2014. Available online: http://www.ine.es/daco/daco42/daco4211/epa0414.pdf (accessed on 23 July 2015). (In Spanish)

6. Chen, W.; Lu, S.; Jiao, W.; Wang, M.; Chang, A.C. Reclaimed water: A safe irrigation water source? Environ. Dev. 2013, 8, 74-83.

7. Herman, J.D.; Zeff, H.B.; Reed, P.M.; Characklis, G.W. Beyond optimality: Multistakeholder robustness tradeoffs for regional water portfolio planning under deep uncertainty. Water Resour. Res. 2014, 50, 7692-7713.

8. Philip, J.-M.; Sanchez-Choliz, J.; Sarasa, C. Technological change in irrigated agriculture in a semiarid region of Spain. Water Resour. Res. 2014, 50, 9221-9235.

9. Aguilera-Klink, F.; Pérez-Moriana, E.; Sánchez-García, F. The social construction of scarcity. The case of water in Tenerife (Canary Islands). Ecol. Econ. 2000, 34, 233-245.

10. Delgado, S.; Rodriguez-Gomez, L.E.; Vera, L.; Alvarez, M.; Diaz, F.; Rodriguez-Sevilla, J. Water reuse in the management of island water resources: The case of the Canary Islands and the Region of Madeira. J. Water Supply Res. Technol. AQUA 2012, 61, 484-493.

11. Palacios, M.P.; Fernandez-Vera, J.R.; Fernández-Pinazo, F.; Echevarria, F.; Hernandez-Moreno, J.M. Desalination versus Reclaimed water reuse under sustainability criteria: The energy point of view. In Proceedings of the UNESCO/UCI International Conference on Water Scarcity, Global Changes, and Groundwater Management, Irvine, CA, USA, December 2008.

12. Consejo Insular de Aguas de Gran Canaria. Avance Plan Territorial Especial Hidrológico de Gran Canaria (PTE 04): Volumen I, Tomo III, Anexo $n^{\circ} 3$ Inventario de Recursos Hídricos; Consejo Insular de Aguas de Gran Canaria: Las Palmas de Gran Canaria, Spain, 2013. (In Spanish)

(C) 2015 by the authors; licensee MDPI, Basel, Switzerland. This article is an open access article distributed under the terms and conditions of the Creative Commons Attribution license (http://creativecommons.org/licenses/by/4.0/). 